\title{
Dieteticpractice and Sleeping Behavior Accountable for Obesity: Ayurvedic and Contemporary Wisdom
}

\author{
Kapil Deo Yadav* and Anand K Chaudhary \\ Shri Krishna Ayurveda Medical College, India
}

Submission: March 30, 2017; Published: April 26, 2017

"Corresponding author: Kapil Deo Yadav, Shri Krishna Ayurveda Medical College, Rauna Khurda, Cholapur, Varanasi, India, Email: k.d.yadav1983@gmail.com

\begin{abstract}
Dietetic practice and sleeping behavior are accountable for upholding synchronization of life and considered as imperative pillars of life. Over-consumption of food any produces stress to the adjacent cell of stomach which enhance NLRP3 inflamma some (components of an intracellular immune response) that initiates low-grade inflammation, whereas intermittent fasting provides resistance to inflammation. Furthermore, it may be responsible for shifting leptin concentration following pathway of chronic low grade inflammation whereas hypercoloic/unbalance diet increases abdominal adipose tissue, impaired insulin sensitivity. Short duration sleepis responsible for increasing appetite which leads to weight gain while day time sleeping is positively associated with neopterin (NP) and causes oxidative stress. It also activates nuclear factor kB subunit which increases inflammatory mediators. Thus, Atypical dietetic practice and sleeping behavior aggravating factors like oxidative stress, inflammation etc., which ultimately favor pathogenesis of obesity.
\end{abstract}

Keywords: Obesity; Dietary habit; Sleeping behavior

\section{Introduction}

Obesity is one of the major health crises and the leading cause of disabilities around the world and predicts that in 2020 , the prevalence of obesity among 35-year-olds will be $30-37 \%$ in men and $34-44 \%$ in women [1]. Diets and lifestyles modification may promote an excessive increase in body fatness or abdominal fatness [2] and differences in food composition are also contributed [3]. Similarly, Sleep is necessary for maintaining the hormonal balance (leptin, ghrelin, insulin etc.) \& blood sugar level within body and obesity positively related with lack of sleep [4].

Ayurveda has an opportunity to establish its supremacy in treatment of Obesity (Sthaulya) on virtue of its fundamentals regarding promotion and prevention of Health such as Dietary habit; Life style and sleeping behavior are considered as three imperative pillars of life. Among them Dietary habit and sleeping behavior is most important factors responsible for maintenance of harmony of body [5]. A survey of 2012 by Premier Inn found that money worries are keeping $37 \%$ of us awake at night, a 2011 survey by IKEA and Which? Found that 7 in 10 feel they aren't getting enough sleep, and the NHS spends over $£ 50$ million on sleeping pills alone [6]. In present article, we proposed the hypothesis that short duration sleep and abnormal dietary habit can lead to obesity.

\section{Dietetic Practice}

Nature of diet i.e. quantity \& quality of diet as well as digestive capacity accountable for adequate growth \& developments of body and any imbalance in it will influence health status. It has been reported that dietary/eating behaviors such as overeating, unhealthy food and breakfast skipping have been associated with the overweight [7]. Furthermore, low consumption of fruits, green vegetables, and milk; increasing consumption of snacks, sweets, and soft drinks and skipping breakfast continuous increase adiposity [8]. In addition to environmental differences eating habit represent the most dominant determinant of increasing the tendency of overweight and obesity and a modification in the eating habits may be singleton tactic strategy to a more appropriate weight control [9].

\section{Nature of Diet}

Excessive eating will be responsible for development of obesity and fasting (caloric restriction) for thinness of body [10]. Increasing westernization, urbanization and mechanization around the world is associated with changes in the diet towards high fat, high energy-dense foods and a sedentary life style. It has been reported that high fat diets are weak satiating, thus promote passive over consumption [11] and food intake has 
been associated with obesity not only in terms of the volume but also in terms of the composition [12]. Over consumption (excess volume of food being ingested) may causes stress to adjacent cells and under stress condition, concentration of NLRP3, inflamma some (components of an intracellular immune response) will be increased in mitochondrial [13] and activates inflammatory processes, that increase TNF- $\alpha$ concentration [14], which initiates low-grade inflammatory process leading to development of obesity. It is also reported that intermittent fasting (intermittent calorie restriction) check the activity of NLRP3 inflamma some mediated by mediated by SIRT3 molecule and ultimately reduces inflammation which is prime cause of obesity [13]. It was reported that SIRT3 not activated only through fasting but also activated by using of nicotinamideriboside and provides resistance to inflammatory response (due to excess caloric consumption) and potentially prevent or reverse obesity-associated diseases of inflammation.

Carbohydrate, protein, fat, vitamins and other essential component in definite ratio (Balance/quality diet) required for normal growth and development, any imbalance may lead to development of overweight/obesity. Carbohydrate rich diet, such as vegetables and cereals, tend to include water and fiber which further dilute energy density whereas fatty diet like oils, butter and margarine, have less water or fiber, this indicate that fatty diet have high energy density [15]. It has been reported that long-chain saturated fatty acids bind to Toll-like receptors (TLR2 and TLR4) of microglia and increases TNF-alpha, IL-1 $\beta$, and IL-6, which destroying the neurons responsible for appetite control [16], so due to lack of feedback mechanism these diet may promote development of obesity. Furthermore, 23\% $\mathrm{w} / \mathrm{v}$ concentration of sugar (Fructose) leads to caloric overconsumption and increases abdominal adipose tissue, impaired insulin sensitivity, plasma free fatty acids and leptin [17] that exacerbated weight gain.

\section{Sleep}

Epidemic of obesity cannot be fully explained by changes in diet (food intake, serving sizes, sugar consumption etc.) and physical activity [18]. As per the sleep is considered as a third pillar of health, which is supported by current researches [19]. Thus Sleep seems to be essential for Biological drives like hunger and thirst. Short-duration and poor-quality sleep which helps in development of obesity and diabetes etc. The gradual decline in sleep duration may disrupt synchrony between feeding/fasting and energy storage/utilization.

\section{Sleeping Behavior}

Sleep plays an important role in the maintenance of health and allows the mind and body to rest. It has been reported that sleep deprivation leads to hormonal changes particularly for the hormones such as leptin, ghrelin, insulin, cortisol and growth hormone, which are involved in appetite control, body composition and energy balance, so it may contribute to the development of overweight and obesity [20]. Short duration sleep(combined daytime and nighttime sleep) was associated with elevated BMI even the twin pairs [21] and associated with low leptin (an appetite suppressor) and high ghrelin levels (an appetite stimulant) [22], which increased appetite ultimately lead to overeating and weight gain. It is reported that short sleep duration associated with insulin resistance [23] and insulin resistance is one of the major cause of obesity, furthermore short duration sleep is also increases cortisol [24], which has lipogenic properties. Thus we assume that short duration sleep promote pathogenesis of obesity due to overeating, insulin resistance and elevated cortisol.

Positive correlation exist between serum Neopterin (NP, biomarker of systemic adaptive immune activation, synthesized by monocyte-derived macrophages and dendritic cell) concentration and BMI and its concentration increases in day sleeping [25]. Higher concentration of NP is positively associated with production of reactive oxygen species and can also be regarded as indicator for oxidative stress. Furthermore, inverse association exists between neopterin and HDL i.e. high NP concentrations were associated with reduced HDL, whereas positive correlation present with waist circumference [26]. It is also reported that NP activates nuclear factor $\mathrm{kB}$ subunit which increases inflammatory mediators [27] and increase waist circumference, oxidative stress, inflammatory mediators and decrease in HDL is associated with obesity [28]. Thus EDS increases serum NP (early inflammation marker) and positively correlated with obesity.

\section{Conclusion}

Dietary practice and sleeping behavior are responsible for maintaining the harmony of life and anomalous dietary practice and sleeping behavior may favors the pathogenesis of obesity by fluctuating the concentration of NLRP3 inflamma some, SIRT3 molecule leptin, ghrelin, neopterin (NP), inflammatory mediators and oxidative stress.

\section{References}

1. Bibbins-Domingo K, Coxson P, Pletcher MJ, Lightwood J, Goldman L (2007) Adolescent overweight and future adult coronary heart disease. N Engl J Med 357(23): 2371-2379.

2. Binkley JK, Eales J, Jekanowski M (2000) The relation between dietary change and rising US obesity. Int J Obes Relat Metab Disord 24(8): 1032-1039.

3. McCrory MA, Fuss PJ, Hays NP, Vinken AG, Greenberg AS, et al. (1999) Overeating in America: association between restaurant food consumption and body fatness in healthy adult men and women ages 19 to 80, Obesity Research 7(6): 564-571.

4. Causes.

5. Charak (2003) CharakSamhita Sutra Sthan $21^{\text {st }}$ Chapter $51^{\text {th }}$ Sloka.

6. http://www.sleepcouncil.org.uk/wp-content/uploads/2013/01/Geta-Good-Nights-Sleep.pdf 
7. Lee HA, Lee WK, Kong KA, Chang N, Ha EH, et al. (2011) The effect of eating behavior on being overweight or obese during preadolescence. J Prev Med Public Health 44(5): 226-233.

8. Hanley JG, Harris SB, Gittlesohn J, Wolever MS, Saksvig B (2000) Overweight among children and adolescents in a Native Canadian Community: Prevalence and associated factors. Am J Clin Nut 71(3): 693-700.

9. Triches RM, Giugliani ER (2005) Obesity, eating habits, and nutritional knowledge among school children. Rev Saude Publica 39(4): 1-7.

10. Charak (2003) Charak Samhita Sutra Sthan $21^{\text {st }}$ Chapter, $4^{\text {th }}$ Sloka.

11. Holt S, Miller JC, Petocz P, Farmakalidis E (1995) A satiety index of common foods. Eur J Clin Nutr 49(9): 675-690.

12. Tarek TA, Ali Ibrahim AS, Ayub A (2008) Overweight and Obesity and their Association with Dietary Habits, and Sociodemographic Characteristics Among Male Primary School Children in Al-Hassa, Kingdom of Saudi Arabia. Indian J Community Med 33(3): 172-181.

13. Mariathasan S, Newton K, MonackD, Vucic D, French D, et al. (2004) Differential activation of the inflamma some by caspase- 1 adaptors ASC and Ipaf. Nature 430(6996): 213-218.

14. NIH researchers find potential target for reducing obesity-related inflammation.

15. Swinburn BA, Caterson I, Seidel JC, James WPT (2004) Diet, nutrition and the prevention of excess weight gain and obesity. Public Health Nutr 7(1A): 123-146.

16. Milanski M, Degasperi G, Coope A, Morari J, DenisR, Cintra DE, et al. (2009) Saturated fatty acids produce an inflammatory response predominantly through the activation of TLR4 signaling in hypothalamus: implications for the pathogenesis of obesity. J Neurosci 29(2): 359-370.

17. Alzamendi A, Giovambattista A, Raschia A, Madrid V, Gaillard RC, et al. (2009) Fructose-rich diet-induced abdominal adipose tissue endocrine dysfunction in normal male rats, Endocrine 35(2):227-232.

18. Gupta N, Goel K, Shah P, Misra A (2012) Childhood obesity in developing countries: epidemiology, determinants, and prevention. Endocr Rev 33(1): 48-70
19. Davison KK, Lawson CT, Davison KK, Lawson CT (2006) Do attributes in the physical environment influence children's physical activity? A review of the literature. Int J Behav NutrPhys Act 3:19.

20. Samuel DA, Pablo HR (2016) Association between the amount of sleep and obesity in Chilean school children. Arch Argent Pediatr 114(2): 114-119.

21. Taheri S, Lin L, Austin D, Young T, Mignot E (2004) Short sleep duration is associated with reduced leptin, elevated ghrelin, and increased body mass index. PLOS Medicine 1(3): e62.

22. Flint J, Kothare SV, Zihlif M, Suarez E, Adams R, et al. (2007) Association between inadequate sleep and insulin resistance in obese children. Journal of Pediatrics 150(4): 364-369.

23. Vgontzas AN, Fernandez-Mendoza J, Liao D, Bixler EO (2013) Insomnia with Objective Short Sleep Duration: the Most Biologically Severe Phenotype of the Disorder Sleep. Med Rev 17(4): 241-254.

24. Ledochowski M, Murr C, Widner B, Fuchs D (1999) Association between insulin resistance, body mass and neopterin concentrations. ClinChimAct 282: 115-123.

25. Shu-Chun C, Heiner B, Stein EV, Øivind M, Per MU, et al. (2016) Cellular immune activity biomarker neopterin is associated hyperlipidemia: results from a large population-based study. Immun Ageing 13:5.

26. Oxenkrug G, Tucker KL, Requintina P, Summergrad P (2011) Neopterin, a Marker of Interferon-Gamma-Inducible Inflammation, Correlates with Pyridoxal-5'-Phosphate, Waist Circumference, HDL-Cholesterol, Insulin Resistance and Mortality Risk in Adult Boston Community Dwellers of Puerto Rican Origin. Am J Neuroprot Neuroregen 3(1): 4852.

27. Wirleitner B, Baier-Bitterlich G, Hoffmann G et al. (1997)Neopterin derivatives to activate NF-kappa B. Free RadicBiol Med 23(1): 177-179.

28. Gomes SF (2016) What is the role of inflammatory mediators on energy metabolism?. Inflammation and Cell Signaling 3(1): 1189.

\section{Your next submission with Juniper Publishers will reach you the below assets}

- Quality Editorial service

- Swift Peer Review

- Reprints availability

- E-prints Service

- Manuscript Podcast for convenient understanding

- Global attainment for your research

- Manuscript accessibility in different formats

( Pdf, E-pub, Full Text, Audio)

- Unceasing customer service

Track the below URL for one-step submission https://juniperpublishers.com/online-submission.php 